\title{
Impact of packaging materials on the quality attributes of potato (Solanum tuberosum $\mathrm{L}$.) during storage
}

Tanveer Abbas ${ }^{1}$, Sartaj Ali ${ }^{1}$, Azhar Hussain ${ }^{1}$, Ishrat Fatima ${ }^{2}$, Babar Hussain $^{3 *}$, Rashid Alam ${ }^{4}$, Zubair Hussain ${ }^{5}$, Qandeel Zehra ${ }^{3}$, Syed Waqar Hussain $^{3}$, Yawar Abbas ${ }^{3}$ and Zuhair Hasnain ${ }^{6}$

1. Department of Agriculture and Food Technology, Karakoram International University, GIlgit-Pakistan

2. Department of Environmental Sciences, Karakoram International University, Gilgit-Pakistan

3. Gilgit-Baltistan Environmental Protection Agency (GB-EPA), Gilgit-Pakistan

4. Department of Food Science and Nutrition, Anhui Agriculture University, Hefei China

5. Institute of Food and Nutrition, University of Sargodha, Sargodha-Pakistan

6. PMAS, Arid Agriculture University Rawalpindi, Rawalpindi-Pakistan

*Corresponding author's email: babar.ses@gmail.com

Citation

Tanveer Abbas, Sartaj Ali, Azhar Hussain, Ishrat Fatima, Babar Hussain, Rashid Alam, Zubair Hussain, Qandeel Zehra, Syed Waqar Hussain, Yawar Abbas and Zuhair Hasnain. Impact of packaging materials on the quality attributes of potato (Solanum tuberosum L.) during storage. Pure and Applied Biology. Vol. 6, Issue 2, pp454-469. http://dx.doi.org/10.19045/bspab.2017.60045

Received: 01/12/2016 Revised: 17/03/2017 Accepted: 10/04/2017 Online First: $15 / 04 / 2017$

\section{Abstract}

A comprehensive study was planned to identify best packaging material for the variety "Lady Rosetta" which has a higher market demand. Three different packaging materials (i.e. jute, polypropylene and cotton bags) shown as $\mathrm{T}_{1}$ (control), $\mathrm{T}_{2}$ (Jute packaging), $\mathrm{T}_{3}$ (Polypropylene net bags) and $\mathrm{T}_{4}$ (Cotton packaging) were used. Physico-chemical (weight loss, total soluble solids, $\mathrm{pH}$, starch and sugars) and functional attributes (ascorbic acids and total phenolic contents) were investigated at 15 days interval during storage $\left(25 \pm 2^{\circ} \mathrm{C}\right)$. The processing performance of stored potato was also assessed in terms of chip crispiness, flavor and color. The physico-chemical parameters investigated revealed an increased weight loss during storage in all samples, however, lower weight loss in polypropylene net bags with a significant difference at $\mathrm{P}$ $\leq 0.05$. Similarly, total soluble solids increased throughout storage in with a minimum mean value in $\mathrm{T}_{3}$, however a decline observed in $\mathrm{pH}$ values with significant difference $(\mathrm{P} \leq 0.05)$. Starch content reduced in the stored samples, while glucose content and total sugars increased significantly $(\mathrm{P} \leq 0.05)$ in all samples. Maximum increase was observed in $\mathrm{T}_{1}$ and minimum in $\mathrm{T}_{3}$. Total phenolic contents showed a slight increase, while ascorbic acid reduced during 105 days storage in all samples. Superior processing results were obtained for the polypropylene stored samples followed by jute and cotton bags. The overall results revealed that polypropylene packaging was found best in maintaining tuber quality attributes up to 105 days during ambient storage. Thus, it is suggested that polypropylene net bags may be used for storage of potato as packaging material.

Keywords: Potato; Packaging material; Quality attributes; Storage 


\section{Introduction}

Potato (Solanum tuberosum) is a member of Solanaceae family and is a perennial herbaceous plant. Potato was cultivated previously in Latin America, Argentina, Chile, Colombia, Bolivia and Peru. It is supposed that the potato cultivar has been derived from wild species originated in South America [1]. Potato production throughout the world is about $364,808,768$ tons in 2014 and its demand in the international market is increase [2]. Potato has more than 4000 known varieties [3] few of the most standard varieties found in Pakistan are red peeled (Asterix, Barna, Courage, Desiree, Lady rosetta etc and white peeled (Agria, Desi, Diamont, Hemes and Sante etc) which yields on large scale and use for culinary purpose and in industry for processing [4].

In Pakistan potato is commonly cultivated vegetable crop in an area of 184972 hectare with annual production of 3392885 tons [5]. Pakistan has multiple seasons for its growth with a large area under cultivation but the export remained only 50,000 tons annually sharing $0.5 \%$ export globally. GilgitBaltistan is rich in production of class potato [6]. Its annual production on Gilgit-Baltistan is estimated about 134031 metric tons (MT). Local consumption is about $17632 \mathrm{MT}$ and the sale in market is 105921 MT with 10479 MT losses due to unsuitable packaging, diseases etc. The cultivated area is 8526 hectares which is increasing per year as it is main cash crop of the province [7].

Potato is rich in carbohydrates and starch is the key component which is a main source of energy and also a good source of lysine protein [8]. A hundred grams of potato provides $90 \mathrm{kcal}$ energy [9]. Potatoes are the main source of vitamin $\mathrm{B}_{6}$ [10]. Potato is low in cholesterol with high potassium and significant antioxidants that protects human beings against circulatory diseases and cancer [11].
Potato is semi delicate crop and store in low temperature to protect from germination and to confirm their regular supply whenever required. Low temperature potato storage is related with low temperature sweetening and is unsuitable in processing potato varieties [12]. Storage of potato in low temperature results in enzymatically hydrolysis of insoluble starch into soluble glucose, fructose and sucrose [13]. Tuber sweetening loss its market value due to formation of acrylamide which turn brown its fried products and bitter in taste [14]. There are high losses of potato in storage that significantly effects the farmer's economy. Packaging material used for potatoes is the effective operation which determine its storage quality.

Packaging systems can be improved using low temperature storage [12]. Frazier [15] used inhibitors and or suppressants to increase storage while ethylene scavengers [16] and irradiation as integrated management to reduce postharvest damages. The packaging materials treated by means of sheets, cloaks, bags, or more solid containers retain different features that regulate gas interchange between the inner and outer packaging environment [17]. In Pakistan large bags made of jute are use in potato industry which has carrying capacity of $100 \mathrm{~kg}$ generally used to stock potato tubers after harvest. Hence an advance engineered packaging methods such as by using polyethylene, polypropylene, polystyrene and wound preventing corrugated cartons are essential to fulfill the basic food safety standard measures [18].

Usage of poor packaging material deteriorates physical properties of potato such as freshness, tuber integrity and nutritional quality of tubers. Moreover there is not such study conducted regarding packaging material of potato in this region. Therefore keeping in view the specified problem a study was conducted to 
investigate the best packaging method for potato with the objectives to analyze the effect of different packaging material on quality and shelf life of stored potato; to identify suitable packaging material for extended storage life of potato; to analyze physico-chemical attribute of potato tubers during storage and to investigate chips quality of stored potato.

\section{Materials and Methods}

Physico-chemical and processing attributes of a commercial potato variety was chosen for evaluation because of the recent increasing in their production and contribution to the processing industry in Pakistan. This variety was harvested from potato research farm Naltar Gilgit in October 2014 and was immediately transferred to the Food Technology Department, Karakoram International University Gilgit, where the trials were carried out. The tubers were graded into homogenous lots of $>50 \mathrm{~mm}$ length, sorted for the exclusion of damaged, diseased and sunburned tubers afterward placed between $15-20{ }^{\circ} \mathrm{C}$ for suberization for one week.

\section{Packaging trial}

Potatoes were packed in different packaging materials of same size $(30 \mathrm{~cm} \times 40 \mathrm{~cm})$ and perforations $(10 \%)$ procured from local market. The set of treatments included

$\mathrm{T}_{1}=$ Control

$\mathrm{T}_{2}=$ Jute packaging (JP)

$\mathrm{T}_{3}=$ Polypropylene net bags $(\mathrm{PP})$

$\mathrm{T}_{4}=$ Cotton packaging $(\mathrm{CP})$

$5 \mathrm{Kg}$ of potato tubers were placed in each replication and $5 \mathrm{~kg}$ tubers were maintained in each treatment for per day analysis. In total $60 \mathrm{Kg}$ potatoes were placed in each treatment later subjected to different physico-chemical and processing analysis at 15 days intervals respectively.

\section{Weight loss}

The weight loss (\%) in different treatments during storage interval was find out by weighting the samples using digital balance
(OHAUS, Model TS4KD Florham Park, NJ, USA).

Weight loss $(\%)=\underline{\text { Initial weight }- \text { Final weight }} \times 100$ Initial weight

\section{Total soluble solids}

Total soluble solid (TSS as Brix ${ }^{\circ}$ ) was recorded with the help of Digital hand refractometer as recommended by [19] method. The instrument was standardized through water at $25 \pm 1^{\circ} \mathrm{C}$ temperature.

pH

The $\mathrm{pH}$ values were recorded by $\mathrm{pH}$ meter (Inolab. WTW series, Germany) as mentioned in [19] method. The calibration of instrument was done through buffers 4,7 and 10 . The reading was carried out by inserting the electrode directly in the homogenized sample in the beaker.

\section{Starch}

Starch estimation was carried out by making the tuber sugar free by the repeated extraction with $80 \%$ is o-propanol. Tubers were dried at $70^{\circ} \mathrm{C}$ and then starch was hydrolyzed by $60 \%$ perchloric acid. The glucose was estimated spectrophotometerically by using anthrone reagent as described by [20].

\section{Sugar}

The sugar content was find out by using Lane and Eynon titration method. The Fehling's solution was apply to estimate reducing sugar (RS), non-reducing sugar (NRS) and total sugars (TS) as used in [19] method.

Total Sugar $(\%)=\frac{4.95(\text { Factor }) \times 250 \text { (Dilution) }}{\text { Weight }} \times 2.5$

\section{Glucose}

The Glucose test strips method was employed to test Glucose content which was imported from Snack Food Association (Arlington Virginia USA). The change in color was correlated with the color chart and the values were recorded in percentage (\%).

\section{Ascorbic acid}

The ascorbic acid concentration was find out by titrametric technique using 2,6 , di- 
chlorophenol indophenol dye (redox dye) as mentioned in [21].

The ascorbic acid contents was determined using the formula

Ascorbic acid $(\mathrm{mg} / 100 \mathrm{~g})=\frac{\text { Dye factor } \times \text { Titration } \times \text { Volume made up }}{\text { Weight of sample } \times \text { Volume of filtrate }} \times 100$

\section{Total phenolic contents}

The total phenolic contents (TPC) was determined using folin-ciocalteu (FC) assay as illustrated by Lachmann et al., (2008) [22] with few modifications.

\section{Potato chips quality evaluation}

In the experiment the potato tubers were processed into potato chips. In order to determine organoleptic evaluation twenty five students with the faculty members of Department of Food Technology selected as judges because they were the habitual consumers of potato chips. The judges graded chips according to their preferences for Crispiness (CRP) and Flavor (FLV) by using five point hedonic scale as described by [20]. The Color (COL) of the chips was compared with British Potato Council (BPC) Frying color chart and the values were showed as approximate L-values.

\section{Statistical analysis}

Results obtained were subjected to statistical analysis by considering the varieties and packaging material as variation source, using two-way analysis of variance (ANOVA). Levels of significance at $\mathrm{P} \leq$ 0.05 were determined by least significant difference test (LSD).

\section{Results and discussion}

\section{Effect on weight loss (\%)}

The general trend was an increase in weight loss (\%) in all treatments; however the rate of weight loss was slower in packaged potato, as compare to control during the storage period (Table 1). Treatment means of packaged potato showed significant difference. Data on weight loss revealed significant differences between all the storage means. The interaction between treatment means and storage intervals showed maximum weight loss $(\%)$ in $\mathrm{T}_{1}$ and minimum in $\mathrm{T}_{3}$ at the end of storage.

$\mathrm{T}_{1}(3.17 \%)$ showed maximum weight loss meanwhile polypropylene packaging $\left(\mathrm{T}_{3}\right)$ $1.71 \%$ showed minimum weight loss till the end of 105 days storage at ambient temperature. However in general potato packed in polypropylene net bags packaging's $\left(\mathrm{T}_{3}\right) \quad 1.71 \%$ showed lesser weight loss as compared to jute and cotton packaging i.e. $\mathrm{T}_{2}(2.24 \%)$ and $\mathrm{T}_{4}(2.25 \%)$ respectively. Among all the treatments weight loss during different storage intervals showed initial increased slowly which subsequently progressively ascended up to $5.98 \%$ and $5.81 \%$ till the end of 105 days interval in $\mathrm{T}_{2}$ and $\mathrm{T}_{4}$ respectively (Table 1 ).

The weight loss in potato was attributed to the water loss through peel tissues due to physiological processes like respiration and sprouting [23]. Different postharvest management techniques are employed in order to increase the storage stability of potatoes like modified atmosphere packaging, controlled atmosphere packaging, coatings, irradiation etc [16]. Controlled atmosphere storage has not been considered suitable for potato storage due to its high rate of respiration under elevated carbon dioxide level [24]. Packaging systems confer barrier properties to the physiological gaseous exchange and resulted in eventual decreased weight loss under storage period [17].

Minimum weight loss during the present study in packaged potato was primarily due to high moisture level and restricted gaseous exchange maintained inside as compare to control. The permeability and type of different packaging materials however showed significant difference in their physiological weight losses during the storage. The application of polypropylene packaging have been found effective in decreasing weight loss during their postharvest storage in different horticultural 
products like potato, tomato and apricot etc $[25,26]$. Conte et al. [27] reported best storage stability under polypropylene based packaging in cherries. Similar results regarding efficacy of polypropylene packaging during post-harvest storage has been reported by [28].

Table 1. Effect of different packaging materials on weight loss (\%) during storage

\begin{tabular}{|l|l|l|l|c|c|c|c|c|c|}
\hline \multirow{2}{*}{ Treatments } & \multicolumn{7}{|c|}{ Days Intervals } & \\
\cline { 2 - 10 } & $\mathrm{D}_{1}$ & $\mathrm{D}_{2}$ & $\mathrm{D}_{3}$ & $\mathrm{D}_{4}$ & $\mathrm{D}_{5}$ & $\mathrm{D}_{6}$ & $\mathrm{D}_{7}$ & $\mathrm{D}_{8}$ & \\
\hline $\mathrm{T}_{1}$ & $0.00^{\mathrm{b}}$ & $0.3580^{\mathrm{z}}$ & $0.8687^{\mathrm{u}}$ & $1.7580^{\mathrm{p}}$ & $2.0620^{\mathrm{m}}$ & $3.9860^{\mathrm{h}}$ & $6.5763^{\mathrm{b}}$ & $9.8090^{\mathrm{a}}$ & $3.1773^{\mathrm{A}}$ \\
\hline $\mathrm{T}_{2}$ & $0.00^{\mathrm{b}}$ & $0.4847^{\mathrm{x}}$ & $0.7877^{\mathrm{v}}$ & $1.1140^{\mathrm{s}}$ & $1.9783^{\mathrm{o}}$ & $2.9890^{\mathrm{k}}$ & $4.5893^{\mathrm{e}}$ & $5.9850^{\mathrm{c}}$ & $2.2410^{\mathrm{C}}$ \\
\hline $\mathrm{T}_{3}$ & $0.00^{\mathrm{b}}$ & $0.3250^{\mathrm{a}}$ & $0.6287^{\mathrm{w}}$ & $0.9370^{\mathrm{t}}$ & $1.4643^{\mathrm{q}}$ & $2.4910^{\mathrm{l}}$ & $3.4933^{\mathrm{i}}$ & $4.3847^{\mathrm{g}}$ & $1.7155^{\mathrm{D}}$ \\
\hline $\mathrm{T}_{4}$ & $0.00^{\mathrm{b}}$ & $0.3883^{\mathrm{y}}$ & $0.7833^{\mathrm{v}}$ & $1.1850^{\mathrm{r}}$ & $1.9873^{\mathrm{n}}$ & $3.2743^{\mathrm{j}}$ & $4.5657^{\mathrm{f}}$ & $5.8137^{\mathrm{d}}$ & $2.2497^{\mathrm{B}}$ \\
\hline & $0.00^{\mathrm{H}}$ & $0.3890^{\mathrm{G}}$ & $0.7671^{\mathrm{F}}$ & $1.2485^{\mathrm{E}}$ & $1.8730^{\mathrm{D}}$ & $3.1851^{\mathrm{C}}$ & $4.8062^{\mathrm{B}}$ & $6.4981^{\mathrm{A}}$ & \\
\hline
\end{tabular}

All the means with different letters are significant at $\mathrm{p} \leq 0.05$

\section{Effect on total soluble solids}

Data pertaining to the total soluble solid (TSS) in potato exhibited general increasing during the storage period. The increase in total soluble solid was more pronounced in $\mathrm{T}_{1}$ as compare to rest of treatments (Table 2). Treatment means indicated minimum retention of total soluble solid in $T_{2}$, followed by $T_{3}$ and $T_{4}$ with significant difference recorded between them. Storage interval means showed significant difference in total soluble solid with minimum value during the 0 day storage period and maximum retention was observed in case of 105 days storage period. Although nonsignificant interaction between treatment means and storage intervals means became significant after the 15 days storage .

Total soluble solid accumulation in all the packaging materials was steady during the early weeks of storage, which progressively increased with the increasing in storage duration. Maximum retention of total soluble solid value estimated in control $\left(6.32\right.$ brix $\left.^{\circ}\right)$ followed by $\mathrm{T}_{3}\left(5.98\right.$ brix $\left.^{\circ}\right)$ and $\mathrm{T}_{4}$ (5.98 brix $^{\circ}$ ) packaging, while minimum accumulation observed in $\mathrm{T}_{2}\left(5.94 \mathrm{brix}^{\mathrm{O}}\right)$ at the end of 105 days storage. Overall different packaging's retained lower total soluble solid accumulation as compared to control. Changes in total soluble solid are directly related with the hydrolytic conversion of insoluble starch polymers into soluble sugars during the post-harvest period [29]. In general conversion of starch into sugar is an important index of ripening in most of climacteric fruits. Physiological conversion of starch into sugars in potato is slower as compare to other fruits and vegetables, however is specifically undesirable due to the eventual loss of color in processed products [30].

Different packaging materials are known to reduce water loss and starch hydrolysis due to lower respiration rate inside storage atmosphere. Increased accumulation of total soluble solid in $\mathrm{T}_{1}$ may be attributed to the increased rate of respiration as compare to the packaged potatoes. Researchers reported modified atmosphere packaging resulted in controlled conversion of starch into sugars in tomato [25] which are in accordance with the findings of present investigations. 
Table 2. Effect of different packaging materials on total soluble solids (Brix ${ }^{0}$ )

\begin{tabular}{|l|l|l|l|l|l|l|l|l|l|}
\hline \multirow{2}{*}{ Treatments } & \multicolumn{7}{|c|}{ Days Intervals } & \multirow{2}{*}{} \\
\cline { 2 - 10 } & $\mathrm{D}_{1}$ & $\mathrm{D}_{2}$ & $\mathrm{D}_{3}$ & $\mathrm{D}_{4}$ & $\mathrm{D}_{5}$ & $\mathrm{D}_{6}$ & $\mathrm{D}_{7}$ & $\mathrm{D}_{8}$ & \\
\hline $\mathrm{T}_{1}$ & $5.65^{\mathrm{r}}$ & $5.77^{\mathrm{lm}}$ & $5.82^{\mathrm{k}}$ & $5.88^{\mathrm{f}}$ & $5.95^{\mathrm{d}}$ & $5.98^{\mathrm{c}}$ & $6.15^{\mathrm{b}}$ & $6.32^{\mathrm{a}}$ & $5.94^{\mathrm{A}}$ \\
\hline $\mathrm{T}_{2}$ & $5.65^{\mathrm{r}}$ & $5.67^{\mathrm{q}}$ & $5.77^{\mathrm{lm}}$ & $5.77^{\mathrm{lmn}}$ & $5.85^{\mathrm{hi}}$ & $5.88^{\mathrm{f}}$ & $5.92^{\mathrm{e}}$ & $5.94^{\mathrm{d}}$ & $5.80^{\mathrm{B}}$ \\
\hline $\mathrm{T}_{3}$ & $5.65^{\mathrm{r}}$ & $5.67^{\mathrm{q}}$ & $5.74^{\mathrm{o}}$ & $5.76^{\mathrm{mn}}$ & $5.78^{\mathrm{l}}$ & $5.84^{\mathrm{ij}}$ & $5.83^{\mathrm{jk}}$ & $5.98^{\mathrm{c}}$ & $5.78^{\mathrm{D}}$ \\
\hline $\mathrm{T}_{4}$ & $5.65^{\mathrm{r}}$ & $5.68^{\mathrm{q}}$ & $5.71^{\mathrm{p}}$ & $5.75^{\mathrm{no}}$ & $5.83^{\mathrm{jk}}$ & $5.86^{\mathrm{gh}}$ & $5.87^{\mathrm{fg}}$ & $5.98^{\mathrm{c}}$ & $5.79^{\mathrm{C}}$ \\
\hline & $5.65^{\mathrm{H}}$ & $5.69^{\mathrm{G}}$ & $5.76^{\mathrm{F}}$ & $5.79^{\mathrm{E}}$ & $5.85^{\mathrm{D}}$ & $5.89^{\mathrm{C}}$ & $5.94^{\mathrm{B}}$ & $6.05^{\mathrm{A}}$ & \\
\hline
\end{tabular}

All the means with different letters are significant at $\mathrm{p} \leq 0.0$

\section{Effect on pH}

Data related to $\mathrm{pH}$ in potatoes exhibited decrease with the increase in storage period; however the rate of decrease in $\mathrm{pH}$ level was faster in $T_{1}$ as compare to other treatments (Table 3). Treatment means showed maximum $\mathrm{pH}$ retention in $\mathrm{T}_{3}$ followed by $\mathrm{T}_{4}$ and $\mathrm{T}_{2}$, while minimum $\mathrm{pH}$ was recorded in $\mathrm{T}_{1}$ and were found statistically different. Significant statistical difference was recorded in all the Storage interval means. Storage interval means progressively decreased from 15 days interval till the 105 days storage. The interaction between treatment means and storage intervals revealed significant difference at $\alpha=0.05$.

Minimum retention of $\mathrm{pH}$ value found in Control (5.93) followed by cotton packaging (5.95) at the end of 105 days storage. Highest $\mathrm{pH}$ value estimated in potato packed in polypropylene net bags (6.06) followed by jute packaging (5.97).

The retention of $\mathrm{pH}$ during storage as result of improved packaging keeps the horticultural commodities more resistant to decay and portent from microbial attack thus improve storage stability and quality. Our results showed that packaged potato retained enhanced $\mathrm{pH}$ value than those left as control, thus presented better storage stability. The decline in $\mathrm{pH}$ during storage alone or in response to different packaging systems has also been reported by researchers in potatoes as well as [31] and in mango [32]. Some researchers have reported decrease in $\mathrm{pH}$ of potato slices intend for processing may cause low acrylamide formation in final products [33]. This is however achieved by intentional soaking of potato slices in different organic acid solutions prior to frying [34].

Table 3. Effect of different packaging materials on $\mathbf{p H}$

\begin{tabular}{|l|l|l|l|l|l|c|c|c|c|}
\hline \multirow{2}{*}{ Treatments } & \multicolumn{7}{|c|}{ Days Intervals } & \multirow{2}{*}{} \\
\cline { 2 - 11 } & $\mathrm{D}_{1}$ & $\mathrm{D}_{2}$ & $\mathrm{D}_{3}$ & $\mathrm{D}_{4}$ & $\mathrm{D}_{5}$ & $\mathrm{D}_{6}$ & $\mathrm{D}_{7}$ & $\mathrm{D}_{8}$ & \\
\hline $\mathrm{T}_{1}$ & $6.10^{\mathrm{a}}$ & $6.02^{\mathrm{hi}}$ & $6.01^{\mathrm{i}}$ & $5.98^{\mathrm{j}}$ & $5.98^{\mathrm{j}}$ & $5.98^{\mathrm{j}}$ & $5.94^{\mathrm{kl}}$ & $5.93^{\mathrm{l}}$ & $5.99^{\mathrm{D}}$ \\
\hline $\mathrm{T}_{2}$ & $6.10^{\mathrm{a}}$ & $6.08^{\mathrm{ab}}$ & $6.06^{\mathrm{def}}$ & $6.05^{\mathrm{efg}}$ & $6.04^{\mathrm{g}}$ & $6.02^{\mathrm{i}}$ & $6.01^{\mathrm{i}}$ & $5.98^{\mathrm{j}}$ & $6.04^{\mathrm{C}}$ \\
\hline $\mathrm{T}_{3}$ & $6.10^{\mathrm{a}}$ & $6.10^{\mathrm{a}}$ & $6.09^{\mathrm{ab}}$ & $6.06^{\mathrm{cd}}$ & $6.06^{\mathrm{de}}$ & $6.05^{\mathrm{efg}}$ & $6.04^{\mathrm{g}}$ & $6.02^{\mathrm{i}}$ & $6.06^{\mathrm{A}}$ \\
\hline $\mathrm{T}_{4}$ & $6.10^{\mathrm{a}}$ & $6.09^{\mathrm{ab}}$ & $6.08^{\mathrm{bc}}$ & $6.08^{\mathrm{b}}$ & $6.06^{\mathrm{de}}$ & $6.04^{\mathrm{fg}}$ & $6.04^{\mathrm{gh}}$ & $5.95^{\mathrm{k}}$ & $6.05^{\mathrm{B}}$ \\
\hline & $6.10^{\mathrm{A}}$ & $6.07^{\mathrm{B}}$ & $6.06^{\mathrm{C}}$ & $6.04^{\mathrm{D}}$ & $6.03^{\mathrm{E}}$ & $6.02^{\mathrm{F}}$ & $6.01^{\mathrm{G}}$ & $5.96^{\mathrm{H}}$ & \\
\hline
\end{tabular}

All the means with different letters are significant at $p \leq 0.05$

\section{Effect on starch}

The variation in starch contents in response to different packaging material showed steady initial increased followed by progressive decline during the storage period (Table 4). Data related to treatment means showed minimum starch content in $\mathrm{T}_{1}, \mathrm{~T}_{4}$ and $\mathrm{T}_{2}$ which were found statistically 
dissimilar. Maximum starch contents were retained in $\mathrm{T}_{3} 18.25 \%$ at 105 days. Storage interval means expressed significant difference between them. Interaction between storage interval and treatment showed maximum starch retention during 15 days of storage.

Maximum starch contents were observed during 15 days of storage with potato packed in polypropylene net bags and jute packaging and also retained maximum starch contents $20.16 \%$ and $19.61 \%$ respectively. The percentage depletion in starch contents by the end of storage in different packaging systems was found minimum in control and cotton packaged potato i.e. $16.01 \%$ and $16.14 \%$ respectively. The textural attributes in potato tubers like consistency, mealiness, sloughing etc are largely associated to its starch properties and subsequent changes during the processing. During physiological growth stages the sugar produced in the potato leaves are translocated to the growing tissues and stored in the form of starch [35].

In the present study maximum starch depletion in control and some other treatments close to sprouting confirmed the above reported findings. The use of suitable packaging material like polypropylene packaging was found efficient in sprout prevention thus retained maximum starch contents by the end of storage period.

During storage transpiration, redistribution and respiration in potato tubers may affect their starch concentrations. The hydrolysis of starch molecules is mediated through the activities of gluco-amylases breaking the $\alpha$ $1 \rightarrow 6$ links of amylopectin generating linear molecules of amylase which subsequently hydrolyzed by invertase and amylases to produce sucrose and reducing sugars respectively [36].

Table 4. Effect of different packaging materials on starch (\%)

\begin{tabular}{|l|l|c|c|c|c|c|c|c|c|}
\hline \multirow{2}{*}{ Treatments } & \multicolumn{7}{|c|}{ Days Intervals } & \\
\cline { 2 - 10 } & $\mathrm{D}_{1}$ & $\mathrm{D}_{2}$ & $\mathrm{D}_{3}$ & $\mathrm{D}_{4}$ & $\mathrm{D}_{5}$ & $\mathrm{D}_{6}$ & $\mathrm{D}_{7}$ & $\mathrm{D}_{8}$ & \\
\hline $\mathrm{T}_{1}$ & $19.60^{\mathrm{b}}$ & $19.22^{\mathrm{d}}$ & $19.02^{\mathrm{f}}$ & $18.25^{\mathrm{j}}$ & $17.24^{\mathrm{m}}$ & $17.22^{\mathrm{m}}$ & $16.34^{\mathrm{q}}$ & $16.01^{\mathrm{s}}$ & $17.86^{\mathrm{D}}$ \\
\hline $\mathrm{T}_{2}$ & $19.60^{\mathrm{b}}$ & $19.62^{\mathrm{b}}$ & $19.34^{\mathrm{c}}$ & $18.54^{\mathrm{g}}$ & $18.54^{\mathrm{g}}$ & $18.02^{\mathrm{l}}$ & $17.24^{\mathrm{m}}$ & $17.02^{\mathrm{o}}$ & $18.49^{\mathrm{B}}$ \\
\hline $\mathrm{T}_{3}$ & $19.60^{\mathrm{b}}$ & $20.16^{\mathrm{a}}$ & $19.23^{\mathrm{d}}$ & $18.34^{\mathrm{i}}$ & $18.43^{\mathrm{h}}$ & $18.46^{\mathrm{h}}$ & $18.35^{\mathrm{i}}$ & $18.25^{\mathrm{j}}$ & $18.85^{\mathrm{A}}$ \\
\hline $\mathrm{T}_{4}$ & $19.60^{\mathrm{b}}$ & $19.13^{\mathrm{e}}$ & $19.05^{\mathrm{f}}$ & $18.12^{\mathrm{k}}$ & $18.05^{\mathrm{l}}$ & $17.12^{\mathrm{n}}$ & $16.45^{\mathrm{p}}$ & $16.14^{\mathrm{r}}$ & $17.96^{\mathrm{C}}$ \\
\hline & $19.60^{\mathrm{A}}$ & $19.53^{\mathrm{B}}$ & $19.16^{\mathrm{C}}$ & $18.32^{\mathrm{D}}$ & $18.06^{\mathrm{E}}$ & $17.71^{\mathrm{F}}$ & $17.09^{\mathrm{G}}$ & $16.85^{\mathrm{H}}$ & \\
\hline
\end{tabular}

All the means with different letters are significant at $\mathrm{p} \leq 0.05$

\section{Effect on total sugars}

Response of potato packaging to total sugar accumulation was almost consistent with the pattern of glucose accumulation during storage. The total sugar accumulation took place at steady rate which increased till the end of storage period (Table 5). Treatment means demonstrated significant difference between packaged potato and those placed as control. Storage interval means showed significant difference between all values with maximum sugar retention at the end of storage. The interaction between treatment means and storage intervals exhibited slow initial increase with relatively stable values during the mid-storage days. The significant increase in sugar contents had been observed by the start 75 days storage being found more momentous in $\mathrm{T}_{1}(917.0 \mathrm{mg} / 100 \mathrm{~g}), \mathrm{T}_{2}$ $\left(879.4 \mathrm{mg} / 100 \mathrm{~g}, \mathrm{~T}_{4}\left(890.1 \mathrm{mg} / 100 \mathrm{~g}\right.\right.$ and $\mathrm{T}_{3}$ (885.7 mg/100g (Table 8). Maximum increase in total sugar contents was recorded in control $(1080.4 \mathrm{mg} / 100 \mathrm{~g})$ followed by the potato packed in cotton $(902.7 \mathrm{mg} / 100 \mathrm{~g})$, polypropylene net bags $(908.4 \mathrm{mg} / 100 \mathrm{~g})$ and jute $(889.3 \mathrm{mg} / 100 \mathrm{~g})$ packaging's. 
Total sugar contents are present in potato primarily in the form of non-reducing sucrose and reducing glucose and fructose [37]. Although the role of sucrose in browning of fried potato products is limited but it may functions as transitory balance in starch degradation process during storage. The hydrolysis of sucrose mediated through enzyme invertase may leads to the formation of glucose and fructose monomers [38]. The presence of either kind of sugars is highly undesirable for the industrial and consumer requirement. The maximum sugar retention was reported at the end of storage period in control which might be due to their closer to dormancy break at the twilight of storage period these finding accede the same as stated [13].

Table 5. Effect of different packaging materials on total sugar $(\mathbf{m g} / \mathbf{1 0 0 g})$.

\begin{tabular}{|l|l|l|l|l|l|l|l|l|l|}
\hline \multirow{2}{*}{ Treatments } & \multicolumn{7}{|c|}{ Days Intervals } & \\
\cline { 2 - 9 } & $\mathrm{D}_{1}$ & $\mathrm{D}_{2}$ & $\mathrm{D}_{3}$ & $\mathrm{D}_{4}$ & $\mathrm{D}_{5}$ & $\mathrm{D}_{6}$ & $\mathrm{D}_{7}$ & $\mathrm{D}_{8}$ & \\
\hline $\mathrm{T}_{1}$ & $820.0^{\mathrm{y}}$ & $848.3^{\mathrm{w}}$ & $868.8^{\mathrm{q}}$ & $889.4^{\mathrm{i}}$ & $899.7^{\mathrm{f}}$ & $917.0^{\mathrm{c}}$ & $987.7^{\mathrm{b}}$ & $1080.4^{\mathrm{a}}$ & $913.91^{\mathrm{A}}$ \\
\hline $\mathrm{T}_{2}$ & $820.0^{\mathrm{y}}$ & $849.3^{\mathrm{v}}$ & $856.4^{\mathrm{t}}$ & $860.6^{\mathrm{r}}$ & $876.7^{\mathrm{o}}$ & $879.4^{\mathrm{n}}$ & $886.4^{\mathrm{j}}$ & $889.3^{\mathrm{i}}$ & $864.77^{\mathrm{D}}$ \\
\hline $\mathrm{T}_{3}$ & $820.0^{\mathrm{y}}$ & $847.3^{\mathrm{x}}$ & $859.6^{\mathrm{s}}$ & $871.0^{\mathrm{p}}$ & $883.3^{\mathrm{l}}$ & $885.7^{\mathrm{k}}$ & $898.7^{\mathrm{g}}$ & $908.4^{\mathrm{d}}$ & $871.76^{\mathrm{C}}$ \\
\hline $\mathrm{T}_{4}$ & $820.0^{\mathrm{y}}$ & $850.8^{\mathrm{u}}$ & $860.7^{\mathrm{r}}$ & $879.9^{\mathrm{m}}$ & $880.4^{\mathrm{m}}$ & $890.1^{\mathrm{h}}$ & $899.0^{\mathrm{g}}$ & $902.7^{\mathrm{e}}$ & $872.96^{\mathrm{B}}$ \\
\hline & $820.00^{\mathrm{H}}$ & $848.94^{\mathrm{G}}$ & $861.38^{\mathrm{F}}$ & $875.23^{\mathrm{E}}$ & $885.03^{\mathrm{D}}$ & $893.03^{\mathrm{C}}$ & $917.97^{\mathrm{B}}$ & $945.22^{\mathrm{A}}$ & \\
\hline
\end{tabular}

All the means with different letters are significant at $\mathrm{p} \leq 0.05$

\section{Effect on glucose}

The effect of different packaging materials on glucose contents showed steady increase throughout the storage period however, the rate of increase in glucose contents varied with the type of packaging material (Table 6). Treatment means showed significant difference in stored potato with $\mathrm{T}_{1} 124.52$ $\mathrm{mg} / 100 \mathrm{~g}$ retained maximum while $\mathrm{T}_{3} 77.17$ $\mathrm{mg} / 100 \mathrm{~g}$ retained minimum glucose contents. Storage interval means also revealed significant difference with maximum value recorded in the last 105 days while minimum during first 15 days storage. The interaction between storage intervals and treatments revealed less significant difference at the start of storage however significant difference have been recorded at the later stages of storage.

Steady increase in glucose contents had been observed in potato during storage however the increase was more pronounced in case of control. The rate of increase in glucose level in control started by the 45 days and gradually increased up to $251.12 \mathrm{mg} / 100 \mathrm{~g}$ by the end of storage. Rapid increase in glucose contents had been recorded in cotton packaging by 60 days. Least glucose contents had been estimated in polypropylene net bags packaged potato.

The amount of reducing sugar contents in potato intending for processing is very critical since it sets the frying color in fried potato products like chips, French fries etc. Both glucose and fructose being reducing sugars in potato have been negatively correlated with chip fry color Blenkinsop et al. [37], however the presence of glucose content are of major food safety concern due to their active participation in toxic acrylamide formation at elevated temperature processing [39]. BiedermannBrem et al. [40] reported that potato destined for frying, roasting or baking should contain maximum of $0.1 \%$ reducing sugars to mitigate likely acrylamide formation. The significant increase in glucose contents at the later stage of storage in treatments like $\mathrm{T}_{1}(251.13 \mathrm{mg} / 100 \mathrm{~g}), \mathrm{T}_{2}$ (157.98 mg/100g), $\mathrm{T}_{3}(149.35 \mathrm{mg} / 100 \mathrm{~g})$, and $\mathrm{T}_{4}(235.64 \mathrm{mg} / 100 \mathrm{~g})$ might be due to the depletion of carbohydrates reserves in tuber close to their sprouting [13]. Potato packed in Polypropylene packaging delayed the 
dormancy break as compare to other treatments thus retained lesser sugar contents at the end of storage. The results presented in the present study lies in close confirmation with the findings of [41].

Table 6. Effect of different packaging materials on glucose $(\mathrm{mg} / \mathbf{1 0 0 g})$

\begin{tabular}{|l|l|c|c|c|c|c|c|c|c|}
\hline \multirow{2}{*}{ Treatments } & \multicolumn{7}{|c|}{ Days Intervals } & \\
\cline { 2 - 9 } & $\mathrm{D}_{1}$ & $\mathrm{D}_{2}$ & $\mathrm{D}_{3}$ & $\mathrm{D}_{4}$ & $\mathrm{D}_{5}$ & $\mathrm{D}_{6}$ & $\mathrm{D}_{7}$ & $\mathrm{D}_{8}$ & \\
\hline $\mathrm{T}_{1}$ & $0.00^{\mathrm{w}}$ & $35.59^{\mathrm{uv}}$ & $78.51^{\mathrm{n}}$ & $114.17^{\mathrm{j}}$ & $140.94^{\mathrm{i}}$ & $179.27^{\mathrm{e}}$ & $196.54^{\mathrm{d}}$ & $251.13^{\mathrm{a}}$ & $124.52^{\mathrm{A}}$ \\
\hline $\mathrm{T}_{2}$ & $0.00^{\mathrm{w}}$ & $34.64^{\mathrm{v}}$ & $52.66^{\mathrm{r}}$ & $72.99^{\mathrm{p}}$ & $75.90^{\mathrm{o}}$ & $108.92^{\mathrm{k}}$ & $149.87^{\mathrm{g}}$ & $157.98^{\mathrm{f}}$ & $81.62^{\mathrm{C}}$ \\
\hline $\mathrm{T}_{3}$ & $0.00^{\mathrm{w}}$ & $34.47^{\mathrm{v}}$ & $66.95^{\mathrm{q}}$ & $47.23^{\mathrm{s}}$ & $75.63^{\mathrm{o}}$ & $102.75^{\mathrm{m}}$ & $140.95^{\mathrm{i}}$ & $149.35^{\mathrm{gh}}$ & $77.17^{\mathrm{D}}$ \\
\hline $\mathrm{T}_{4}$ & $0.00^{\mathrm{w}}$ & $36.62^{\mathrm{u}}$ & $38.33^{\mathrm{t}}$ & $74.22^{\mathrm{op}}$ & $106.12^{\mathrm{l}}$ & $147.75^{\mathrm{h}}$ & $198.68^{\mathrm{c}}$ & $235.46^{\mathrm{b}}$ & $104.65^{\mathrm{B}}$ \\
\hline & $0.00^{\mathrm{H}}$ & $35.33^{\mathrm{G}}$ & $59.11^{\mathrm{F}}$ & $77.15^{\mathrm{E}}$ & $99.64^{\mathrm{D}}$ & $134.67^{\mathrm{C}}$ & $171.51^{\mathrm{B}}$ & $198.48^{\mathrm{A}}$ & \\
\hline
\end{tabular}

All the means with different letters are significant at $p \leq 0.05$

\section{Effect on ascorbic acid}

In response to different packaging systems the ascorbic acid was among the parameters, which decrease with the increase in storage time (Table 7). The decrease was highly significant in control as compare to all other treatments. Treatment means showed maximum ascorbic acid retention in $T_{3}$ $(24.02 \mathrm{mg} / 100 \mathrm{~g})$ followed by $\mathrm{T}_{2}(23.84$ $\mathrm{mg} / 100 \mathrm{~g})$ and $\mathrm{T}_{4}(23.08 \mathrm{mg} / 100 \mathrm{~g})$. Storage Interval means showed significant difference in their ascorbic acid contents with maximum value retained during 0 days storage and minimum during the 105 days interval. The interaction between storage intervals and treatments showed substantial ascorbic acid retention in packaged potato as compare to control. Ascorbic acid contents observed by at the end of storage in $T_{2}$ $(21.56 \mathrm{mg} / 100 \mathrm{~g})$ and $\mathrm{T}_{3}(21.45 \mathrm{mg} / 100 \mathrm{~g})$ were found greater than those identified in $\mathrm{T}_{1}(15.64 \mathrm{mg} / 100 \mathrm{~g})$.

Amongst different treatments, potato packed in polypropylene net bags packaging and jute packaging retained maximum ascorbic acid contents by the end of storage period. In general the maximum reduction in ascorbic acid contents was observed during the last 90 and 105 days storage.

Ascorbic acid is one of the most important water soluble vitamins required in human diet and much of it is supplied by fresh fruits and vegetables. It is the predominant vitamin in potato and of significant functional importance [42]. Depletion of ascorbic acid has been implicated with reduced nutritional quality therefore their assured stability during storage has been focal concern for post-harvest technologists [43]. Hagg et al. [44] reported that ascorbic acid contents significantly decreases during storage of potato. The reduction is ascribed to the oxidation of ascorbic acid into dehydro ascorbic acid and afterward to diketo-gluconic acid. Being water soluble vitamin and susceptible to oxidation ascorbic acid contents rapidly decreased with the increase rate of respiration and subsequent water loss.

Facts framed in the present study revealed continuous reduction in ascorbic acid contents which was found extensive in control. The application of different packaging systems especially of Polypropylene and polyethylene material reduced the rate of water loss from potato and conferred barrier to the gaseous exchange thus preventing the loss and oxidation of ascorbic acid as compare to control. The efficacy of modified atmosphere packaging in retention of high ascorbic acid contents in fruits and vegetables have also been reported by Conte et al., Calderon et al. and Sammi and Masud $[25,27,28]$. 
Table 7. Effect of different packaging materials on ascorbic acid (mg/100g)

\begin{tabular}{|l|l|l|l|l|l|l|l|l|l|}
\hline \multirow{2}{*}{ Treatments } & \multicolumn{7}{|c|}{ Days Intervals } & \\
\cline { 2 - 9 } & $\mathrm{D}_{1}$ & $\mathrm{D}_{2}$ & $\mathrm{D}_{3}$ & $\mathrm{D}_{4}$ & $\mathrm{D}_{5}$ & $\mathrm{D}_{6}$ & $\mathrm{D}_{7}$ & $\mathrm{D}_{8}$ & \\
\hline $\mathrm{T}_{1}$ & $27.00^{\mathrm{a}}$ & $25.33^{\mathrm{d}}$ & $23.63^{\mathrm{h}}$ & $23.07^{\mathrm{k}}$ & $22.07^{\mathrm{m}}$ & $20.12^{\mathrm{q}}$ & $18.05^{\mathrm{r}}$ & $15.64^{\mathrm{s}}$ & $21.86^{\mathrm{D}}$ \\
\hline $\mathrm{T}_{2}$ & $27.00^{\mathrm{a}}$ & $25.13^{\mathrm{e}}$ & $24.88^{\mathrm{f}}$ & $23.55^{\mathrm{h}}$ & $23.32^{\mathrm{i}}$ & $23.13^{\mathrm{jk}}$ & $22.16^{\mathrm{m}}$ & $21.56^{\mathrm{n}}$ & $23.84^{\mathrm{B}}$ \\
\hline $\mathrm{T}_{3}$ & $27.00^{\mathrm{a}}$ & $26.12^{\mathrm{b}}$ & $25.55^{\mathrm{c}}$ & $25.13^{\mathrm{e}}$ & $23.26^{\mathrm{ij}}$ & $22.34^{\mathrm{l}}$ & $21.33^{\mathrm{o}}$ & $21.45^{\mathrm{no}}$ & $24.02^{\mathrm{A}}$ \\
\hline $\mathrm{T}_{4}$ & $27.00^{\mathrm{a}}$ & $25.44^{\mathrm{cd}}$ & $24.34^{\mathrm{g}}$ & $23.12^{\mathrm{jk}}$ & $22.05^{\mathrm{m}}$ & $21.46^{\mathrm{no}}$ & $21.06^{\mathrm{p}}$ & $20.16^{\mathrm{q}}$ & $23.08^{\mathrm{C}}$ \\
\hline & $27.00^{\mathrm{A}}$ & $25.50^{\mathrm{B}}$ & $24.60^{\mathrm{C}}$ & $23.72^{\mathrm{D}}$ & $22.67^{\mathrm{E}}$ & $21.76^{\mathrm{F}}$ & $20.65^{\mathrm{G}}$ & $19.70^{\mathrm{H}}$ & \\
\hline
\end{tabular}

All the means with different letters are significant at $\mathrm{p} \leq 0.05$

\section{Effect on total phenolic contents}

Total phenolic contents (TPC) showed initial decreasing trend which started to increase at the end of storage period (Table 8). Considerable decline in total phenolic contents was observed in control as compare to packaged potatoes. Treatment means showed significant difference in total phenolic contents in response to different packagings. $\mathrm{T}_{3}$ (138.44 mg/GAE/100g d.w.) maintained maximum total phenolic contents followed by $\mathrm{T}_{2}(142.85 \mathrm{mg} / \mathrm{GAE} / 100 \mathrm{~g}$ d.w.) and $\mathrm{T}_{4}(145.25 \mathrm{mg} / \mathrm{GAE} / 100 \mathrm{~g}$ d.w.) While minimum were observed in $\mathrm{T}_{1}$ (154.75 mg/GAE/100g d.w.). Storage interval means expressed significant difference with maximum determined in 60 days storage while minimum estimated in 0 days interval $(141.04 \mathrm{mg} / \mathrm{GAE} / 100 \mathrm{~g}$ d.w.). The interaction between treatments and storage intervals showed maximum total phenolic contents in $\mathrm{T}_{3}(157.75$ $\mathrm{mg} / \mathrm{GAE} / 100 \mathrm{~g}$ d.w.) and during 105 days storage.
Total phenolic contents are bioactive compounds responsible for various significant physiological processes like enzyme activity, nutrient uptake, protein synthesis [45]. They acts as substrate in potato browning mediated through the activities of poly phenol oxidase enzymes and molecular oxygen followed by subsequent melanin formation [46]. High retention of total phenolic contents during storage is attributed to low poly phenol oxidase and momentous anti-oxidant activity in potatoes [11]. During storage total phenolic contents in potato continued to increase [47] till the onset of poly phenol oxidase activity. The presence of ample molecular oxygen in control caused significant decline in total phenolic contents as compare to other treatments. Our results indicated that packaging materials in general polypropylene in particular curtail the decline in total phenolic contents as compare to control which are also in line with the findings of [48].

Table 8. Effect of different packaging materials on total phenolic contents (mg GAE/100g d.w)

\begin{tabular}{|l|l|c|c|c|c|c|c|c|c|}
\hline \multirow{2}{*}{ Treatments } & \multicolumn{7}{|c|}{ Days Intervals } & \\
\cline { 2 - 9 } & $\mathrm{D}_{1}$ & $\mathrm{D}_{2}$ & $\mathrm{D}_{3}$ & $\mathrm{D}_{4}$ & $\mathrm{D}_{5}$ & $\mathrm{D}_{6}$ & $\mathrm{D}_{7}$ & $\mathrm{D}_{8}$ & \\
\hline $\mathrm{T}_{1}$ & $112.00^{\mathrm{z}}$ & $125.06^{\mathrm{s}}$ & $133.03^{\mathrm{o}}$ & $141.04^{\mathrm{k}}$ & $154.75^{\mathrm{b}}$ & $133.05^{\mathrm{o}}$ & $124.05^{\mathrm{t}}$ & $114.96^{\mathrm{x}}$ & $129.74^{\mathrm{D}}$ \\
\hline $\mathrm{T}_{2}$ & $112.00^{\mathrm{z}}$ & $113.53^{\mathrm{y}}$ & $119.63^{\mathrm{v}}$ & $137.76^{\mathrm{m}}$ & $142.85^{\mathrm{i}}$ & $150.25^{\mathrm{e}}$ & $153.5^{\mathrm{d}}$ & $142.24^{\mathrm{j}}$ & $133.98^{\mathrm{B}}$ \\
\hline $\mathrm{T}_{3}$ & $112.00^{\mathrm{z}}$ & $113.49^{\mathrm{y}}$ & $121.06^{\mathrm{u}}$ & $131.04^{\mathrm{p}}$ & $138.44^{\mathrm{l}}$ & $144.36^{\mathrm{h}}$ & $154.35^{\mathrm{c}}$ & $157.75^{\mathrm{a}}$ & $134.06^{\mathrm{A}}$ \\
\hline $\mathrm{T}_{4}$ & $112.00^{\mathrm{z}}$ & $118.07^{\mathrm{w}}$ & $124.06^{\mathrm{t}}$ & $136.13^{\mathrm{n}}$ & $145.24^{\mathrm{g}}$ & $148.55^{\mathrm{f}}$ & $130.4^{\mathrm{q}}$ & $127.24^{\mathrm{r}}$ & $130.22^{\mathrm{C}}$ \\
\hline & $112.00^{\mathrm{H}}$ & $117.54^{\mathrm{G}}$ & $124.44^{\mathrm{F}}$ & $136.50^{\mathrm{D}}$ & $145.32^{\mathrm{A}}$ & $144.05^{\mathrm{B}}$ & $140.59^{\mathrm{C}}$ & $135.55^{\mathrm{E}}$ & \\
\hline
\end{tabular}

All the means with different letters are significant at $\mathrm{p} \leq 0.05$ 


\section{Effect on chip flavor}

Chips flavor (CFL) estimated as scores recorded by the judges showed an initial increase and eventual decreasing trend in all the treatments during the storage (Table 9). The treatment means exhibited maximum chips flavor scores recorded in $\mathrm{T}_{3}$ (4.26) followed by $\mathrm{T}_{2}$ (3.99), $\mathrm{T}_{4}$ (3.75) and minimum found in $\mathrm{T}_{1}(3.65)$. The means of storage intervals showed maximum chips flavor during the mid-storage intervals while minimum were articulated during the start and end of the storage. The interaction between storage intervals and treatments showed minimum (2.72/5.00) and maximum (4.61/5.00) scores in $T_{1}$ and $T_{2}$ respectively during storage. In general chips flavor scores increased in all the treatments after
30 days storage which started to decline after 60 days storage in most of the treatments. Potatoes Flavor is the sensory impression of food detected by the blend of taste and smell senses. It is the overall resultant impression derived by the taste buds in mouth and aroma detected by olfactory epithelium in nose. Flavor evolution in potato chips is primarily attributed to the oil uptake and corresponding volatile formations during thermal processing [49]. In the present study generally chips flavor scores were found in consistent with the other quality attributes in potato chips. The maximum chips flavor scores were identified in polypropylene net bags and jute packaged potatoes as compare to control.

Table 9. Effect of different packaging materials on chip flavor (scores)

\begin{tabular}{|c|c|c|c|c|c|c|c|}
\hline \multirow[t]{2}{*}{ Treatments } & \multicolumn{6}{|c|}{ Days Intervals } & \\
\hline & $\mathrm{D}_{1}$ & $\mathrm{D}_{2}$ & $\mathrm{D}_{3}$ & $\mathrm{D}_{4}$ & $\mathrm{D}_{5}$ & $\mathrm{D}_{6}$ & \\
\hline $\mathrm{T}_{1}$ & $3.5000^{\mathrm{e}}$ & $3.5200^{\mathrm{e}}$ & $4.3600^{\mathrm{abc}}$ & $4.3300^{\mathrm{abcd}}$ & $3.5133^{\mathrm{e}}$ & $2.7267^{f}$ & $3.6583^{C}$ \\
\hline $\mathrm{T}_{2}$ & $3.5000^{\mathrm{e}}$ & $3.6167^{\mathrm{e}}$ & $4.5200^{\mathrm{ab}}$ & $4.6100^{\mathrm{a}}$ & $4.0100^{\text {bcde }}$ & $3.7267^{\mathrm{e}}$ & $3.9972^{\mathrm{B}}$ \\
\hline $\mathrm{T}_{3}$ & $3.5000^{\mathrm{e}}$ & $4.6200^{\mathrm{a}}$ & $4.6300^{\mathrm{a}}$ & $4.5133^{\mathrm{ab}}$ & $4.3300^{\mathrm{abcd}}$ & $4.0100^{\text {bcde }}$ & $4.2672^{\mathrm{A}}$ \\
\hline $\mathrm{T}_{4}$ & $3.5000^{\mathrm{e}}$ & $3.7633 \mathrm{~d}^{\mathrm{e}}$ & $3.8300^{\text {cde }}$ & $4.0100^{\text {bcde }}$ & $3.9200^{\text {cde }}$ & $3.5200^{\mathrm{e}}$ & $3.7572^{\mathrm{C}}$ \\
\hline & $3.5000^{\mathrm{C}}$ & $3.8800^{\mathrm{B}}$ & $4.3350^{\mathrm{A}}$ & $4.3658^{\mathrm{A}}$ & $3.9433^{\mathrm{B}}$ & $3.4958^{\mathrm{C}}$ & \\
\hline
\end{tabular}

All the means with different letters are significant at $p \leq 0.05$

\section{Effect on chip crispiness}

Chip crispiness (CCR) scores showed a steady increase followed by final decrease in all the treatments however the rate of decrease in chip crispiness scores was found lower in packaged potatoes as compare to control (Table 10). Treatment means revealed significant difference in all the treatments and were also found statistically dissimilar at $5 \%$ level of significance. Storage interval means showed initial increase in chip crispiness scores which remained persistent during the most of storage time and found minimum during the end of storage. The interaction between treatments and storage intervals showed maximum chip crispiness scores in $T_{3}$ (4.76) and $\mathrm{T}_{4}$ (4.61) on $45^{\text {th }}$ day. Minimum chip crispiness scores were identified in control in $\mathrm{T}_{1}(2.35)$ at the end of storage.

Chip crispiness scores expressed in $\mathrm{T}_{3}$ (4.01) at the end of storage were found similar to those identified on $30^{\text {th }}$ day of storage in $\mathrm{T}_{1}$ (4.01). Over all percentage declines in chip crispiness scores was found maximum in Control and minimum in Polypropylene net bags packaged potatoes during storage.

Potato chip texture is often described as crispiness which is an important sensorial attribute for consumer's appreciations. Eminent crispy structure develops in potato chip due to the hardening of chip crust during frying at elevated temperature [50]. Crispiness in potato chips is dependent on 
the excellence of raw material and improved processing techniques. Potato tubers with high specific gravity and dry matter contents reported to produce potato chips with high crispiness value predominantly influenced by starch and non-starch polysaccharides (proto pectin) contents [20]. Jaswal [51] reported that the potato with high specific gravity contain high molecular weight, stable and compact polysaccharides (starch, pectin etc.) contents preventing their integrity thus contributing to their appreciable textural configurations during frying. In the present study the potato tubers with high specific gravity value maintained appreciable chip crispiness scores in the fried products. Although chip crispiness scores with in most of packaging materials remained statistically in significant however potatoes with high specific gravity value produced chips with appreciable chip crispiness value as compare to control which confirmed the findings reported by the researchers above.

Table 10. Effect of different packaging materials on chip crispiness (scores)

\begin{tabular}{|c|c|c|c|c|c|c|c|}
\hline \multirow[t]{2}{*}{ Treatments } & \multicolumn{6}{|c|}{ Days Intervals } & \\
\hline & $\mathrm{D}_{1}$ & $\mathrm{D}_{2}$ & $\mathrm{D}_{3}$ & $\mathrm{D}_{4}$ & $\mathrm{D}_{5}$ & $\mathrm{D}_{6}$ & \\
\hline $\mathrm{T}_{1}$ & $4.0000^{\mathrm{h}}$ & $4.3800^{\mathrm{d}}$ & $4.0100^{\mathrm{h}}$ & $3.7433^{j}$ & $3.1533^{\mathrm{m}}$ & $2.3533^{n}$ & $3.6067^{\mathrm{D}}$ \\
\hline $\mathrm{T}_{2}$ & $4.0000^{\mathrm{h}}$ & $4.3200^{\mathrm{e}}$ & $4.1433^{g}$ & $4.2167^{\mathrm{f}}$ & $3.8200^{\mathrm{i}}$ & $3.5100^{\mathrm{k}}$ & $4.0017^{\mathrm{C}}$ \\
\hline $\mathrm{T}_{3}$ & $4.0000^{\mathrm{h}}$ & $4.2300^{\mathrm{f}}$ & $4.4200^{c}$ & $4.7667^{\mathrm{a}}$ & $4.3600^{\mathrm{d}}$ & $4.0133^{\mathrm{h}}$ & $4.2983^{\mathrm{A}}$ \\
\hline $\mathrm{T}_{4}$ & $4.0000^{\mathrm{h}}$ & $4.2200^{\mathrm{f}}$ & $4.1567^{\mathrm{g}}$ & $4.6133^{b}$ & $3.8300^{\mathrm{i}}$ & $3.4100^{1}$ & $4.0383^{\mathrm{B}}$ \\
\hline & $4.0000^{\mathrm{D}}$ & $4.2875^{\mathrm{B}}$ & $4.1825^{\mathrm{C}}$ & $4.3350^{\mathrm{A}}$ & $3.7908^{\mathrm{E}}$ & $3.3217^{\mathrm{F}}$ & \\
\hline
\end{tabular}

All the means with different letters are significant at $\mathrm{p} \leq 0.05$

\section{Effect on chip color}

Chip color (CCL) recorded in terms of approximate L-value showed steady decrease with the increase in storage time (Table 11). The treatments means illustrated minimum chip color value in $\mathrm{T}_{1}$ (61.20) and $\mathrm{T}_{2}$ (62.18) while all other treatments $\mathrm{T}_{3}$ (63.53) and $\mathrm{T}_{4}$ (62.67) were found statistically dissimilar (at $\alpha=0.05$ ). Storage interval means showed maximum chip color values during the 0 days and minimum at the end of storage. The interaction between treatments and storage intervals showed maximum chip color value during the start of storage in all the treatments and minimum in $T_{1}$ and $T_{2}$ at the end of storage period. Packaged potatoes expressed appreciable chip color value during the storage as compare to control. Maximum chip color value (64.01) was identified in polypropylene net bags packaged potatoes however remained statistically similar to the most of other treatments at the end of storage.

Chip color is the most important quality parameter sternly related to the consumer perception for the product acceptance [52]. Potato chip color is the consequence of Maillard reaction primarily related to the presence of reducing sugars, protein, frying temperature and duration [53]. In addition the chip color value is an important index of toxic acrylamide formation in potato during high temperature processing [54].

Chip color values in the present investigation were quantified on the basis of approximate L-values as described in fry color chart by British Potato Council (BPC, $\mathrm{UK}) . \quad \mathrm{L}^{*}$ is the luminance having colorimeteric value ranges between 0 (Black) to 100 (Light) however the L-value for potato chips color presented in the fry color chart ranged between 65 (Grade-I) to 49 (Grade-V). In general the chip color values remained statistically similar in 
response to most of the packaging applications however found minimum in control as compare to all other treatments. Since the frying temperature and duration remained constant factors in potato processing thus presence of reducing sugars being the major determinant of chip color values during storage. Potato with low reducing sugar contents retained maximum chip color value as happened in packaged potatoes during storage. The correlation between reducing sugar contents and potato chip color has also been reported by different researchers like $[39,40,55]$.

Table 11. Effect of different packaging materials on Chip Color (L-value)

\begin{tabular}{|c|c|c|c|c|c|c|c|}
\hline \multirow[t]{2}{*}{ Treatments } & \multicolumn{6}{|c|}{ Days Intervals } & \\
\hline & $\mathrm{D}_{1}$ & $\mathrm{D}_{2}$ & $\mathrm{D}_{3}$ & $\mathrm{D}_{4}$ & $\mathrm{D}_{5}$ & $\mathrm{D}_{6}$ & \\
\hline $\mathrm{T}_{1}$ & $65.00^{\mathrm{a}}$ & $63.01^{\mathrm{f}}$ & $61.65^{\mathrm{i}}$ & $60.68^{1}$ & $59.36^{\mathrm{n}}$ & $57.53^{p}$ & $61.20^{D}$ \\
\hline $\mathrm{T}_{2}$ & $65.00^{\mathrm{a}}$ & $64.01^{b}$ & $63.25^{\mathrm{e}}$ & $62.04^{\mathrm{h}}$ & $60.75^{\mathrm{k}}$ & $58.04^{\circ}$ & $62.18^{C}$ \\
\hline $\mathrm{T}_{3}$ & $65.00^{\mathrm{a}}$ & $64.01^{b}$ & $64.00^{\mathrm{b}}$ & $63.54^{\mathrm{d}}$ & $62.63^{\mathrm{g}}$ & $62.03^{\mathrm{h}}$ & $63.53^{A}$ \\
\hline $\mathrm{T}_{4}$ & $65.00^{\mathrm{a}}$ & $64.01^{b}$ & $63.72^{c}$ & $62.03^{\mathrm{h}}$ & $61.26^{\mathrm{j}}$ & $60.02^{\mathrm{m}}$ & $62.67^{B}$ \\
\hline & $65.00^{A}$ & $63.76^{B}$ & $63.16^{\mathrm{C}}$ & $62.07^{\mathrm{D}}$ & $61.00^{\mathrm{E}}$ & $59.40^{F}$ & \\
\hline
\end{tabular}

All the means with different letters are significant at $\mathrm{p} \leq 0.05$

\section{Conclusions}

In this study three packaging material (cotton, jute and propylene net bags) were tested against potato tuber to maintain quality during storage. From the results it was concluded that propylene net bags showed efficient packaging material followed by jute. So it is recommended that propylene net bags may be used as a packaging material for potato tuber during storage. Moreover the "Lady Rosetta" found as superior processing variety for potato manufacturing owing to its appropriate size and shape, high dry matter and reducing sugar with best processing performance.

\section{Authors' contributions}

Conceived and designed the experiments: S Ali \& A Hussain, Performed the experiments: T Abbas, Analyzed the data: T Abbas, SW Hussain \& $\mathrm{Z}$ Hasnain, Contributed reagents/ materials/ analysis tools: I Fatima, Q Zehra \& Y Abbas, Wrote the paper: B Hussain, R Alam \& Z Hussain, Corresponding author: B Hussain.

\section{Acknowledgment}

The author is thankful to Department of Agriculture and Food Technology, Karakoram International University for providing fund and lab facility. The writer also thankful to his supervisor for assistance and support. The author specially acknowledge Mr. Babar Hussain for helping in preparing the manuscript.

\section{References}

1. Hawkes JG (1962b). The origin of Solanum juzepczukii Buk. and $S$. curtilobum Juz. et Buk . Z. Pflanzenziicht 47: 1-14.

2. FAOSTAT (2014). Food Outlook No. 1, FAOSTAT, Rome.

3. Burlingame B, Mouille B \& Charrondiere R (2009). Nutrients, bioactive nonnutrients and anti-nutrients in potatoesA Critical Review. J Food Composition and Anal 22: 494-502.

4. PHDEB, Pakistan Horticulture Development and Export Board (2008). Potato Marketing Strategy pp. 29.

5. Government of Pakistan. 2012. Economic Survey, Finance Division, Economic Advisors Wings, Islamabad-Pakistan.

6. Hawkes JG (1978). Biosystematics of the potato. In: P.M. Harris (Ed.), The Potato Crop: the Scientific Basis for Improvement, pp. 15-69. Chapman \& Hall, London. 
7. DOA (Directorate of Agriculture Gilgit) 2009. Annual Statistical Report (Unpublished Report).

8. Gravoueille JM (1999). Utilization en la alimentacionhumana (Use in the human feeding) Rouselle P., Y. Robert and J. C. Crosnier. (Eds). La Patato (The potato) Mundi prensa Madrid pp: 459508.

9. Raban A, Tagliabue A, Christensen NJ, Madsen J, Host JJ \& Astrup A (1994). Resistant starch: the effect on postprandial glycemia, hormonal response, and satiety. Am J Clin Nutr 60: 544-551.

10. Kolasa KM (1993). The potato and human nutrition. Am Potato J 70: 375384.

11. Lachmann J, Hamouz K, Orsak M \& Pivec V (2008). The influence of flesh colour and growing locality on polyphenolic content and antioxidant activity in potatoes. Scientia Horticulture 117: 109-114.

12. Kyriacou MC, Ioannides IM, Gerasopoulos D \& Siomos AS 2009. Storage profile and processing potential of four potato (Solanum tuberosum .L) cultivars under these storage temperature regimes. J Food Agri and Env 7(1): 31-37.

13. Sowokinos JR 1990. Stress induced alteration in carbohydrate metabolism. In: The Molecular and Cellular Biol. Potato, $M$ E Vayda and W D Park (Eds.) Wallingford, UK: $\quad C A B$ International pp. 137-158.

14. Mottram DS, Wedzicha BL \& Dodson AT (2002). Acrylamide is formed in the Maillard reaction. Nature 419: 448-449.

15. Frazier MJ, Olsen NL \& Kleinkopf GE (2004). Organic and alternative methods of potato sprout control in storage. University of Idaho Extension, USA.
16. Abbasi KS, Hassan M \& Ahmad A (2004). Effect of different ethylene absorbents on the storage of banana (Musa cavendishii cv. Basrai). Pak J Arid Agric 7(1): 1-11.

17. Hong SL \& Krochta JM (2003). Oxygen Barrier Properties of Whey Protein Isolate Coating on Polypropylene Films. J Food Sci 68: 224-228.

18. Abbasi KS, Masud T, Qayyum A, Khan SU, Ahmad A, Mehmood A, Farid A \& Jenks MA (2016). Transition in tuber quality attributes of potato (Solanum tuberosum L.) under different packaging systems during storage. Journal of Applied Botany and Food Quality 89: 142-149.

19. AOAC (2005). Official Methods of Analysis. Association of Official Analytical Chemists. $16^{\text {th }}$ ed. Washington D.C, USA.

20. Kita A (2002). The influence of potato chemical composition on crisp texture. Food Chem 76: 173-179.

21. Kumar D, Ezekiel R, Singh B \& Ahmed I (2005). Conversion table for specific gravity, dry matter and starch content from under water weight of potatoes grown in North Indian plains. Potato $J$ 32: 79-84.

22. AOAC (1990). Official methods of analysis of the Association of Official Analytical Chemists, 15th ed., Association of Official Analytical Chemists, Arlington VA pp. 10581059.

23. Tester RF, Ansell R, Snape CE \& Yusuph M (2005). Effect of storage temperatures and annealing conditions on the structure and properties of potato (Solanum tuberosum L.) starch. Intl J Biological Macromolecules 36: $1-8$.

24. Fonseca SC, Oliveira FAR \& Brecht JK (2002). Modeling respiration rate of fresh fruits and vegetables for 
modified atmosphere packages: A review. J Food Engineering 52: 99-11.

25. Saammi S \& Masud T (2007). Effect of different packaging systems on storage life and quality of tomato (Lycopersicon esculentum var. riogrande) during different ripening stages. Intl J Food Safety 9: 37-40.

26. Abbasi KS, Anjum N, Sammi S, Masud T \& Ali S (2011). Effect of Coatings and Packaging Material on the Keeping Quality of Mangoes (Mangifera indica L.) stored at Low Temperature. Pak J Nutr 10(2): 129138.

27. Conte A, Socrocco C, Lecce L, Mastromatteo M \& Nobile MAD (2009). Ready-to-eat sweet cherries: Study on different packaging systems. Innovative Food Sci Emer Technol 10(4): 564-571.

28. Calderon MM, Grau MAR \& Belloso OM (2008). Effect of packaging conditions on quality and shelf life of fresh cut pineapple (Ananascomosus). Post-harvest Biol Technol 50(2-3): 182-189.

29. Kittur FS, Kumar KR \& Tharanathan RN (1998). Functional Packaging Properties of Chitosan Films. Eur Food Res Technol 44: 206-208.

30. Tamaki DS, Ichi HJ \& Kazuhiko I (2003). Effects of Low Temperature Storage on the Quality of Different Processing Cultivars of Potato Tubers. Food Pres Sci 29(5): 275-279.

31. Nourian F, Ramaswamy HS \& Kushalappa AC (2003). Kinetics of quality change associated with the potatoes stored at different temperatures. Lebens-Wiss and Technol 36: 49-65.

32. Manzano JE, Perez Y \& Rojas E (1997). Coating waxes on Haden mango fruits (Mangifera indica L.) cultivar for export. Acta. Hort 455: 738-746.
33. Jung MY, Choi DS \& Ju JW (2003). A novel technique for limitation of acrylamide formation in fried and baked corn chips and in French fries. $J$ Food Sci 68: 1287-1290.

34. Pedreschi F, Kaack K \& Granby K (2004). Reduction of acrylamide formation in potato slices during frying. Lebensm-Wiss and Technol 37: 679-685.

35. Fernie AR, Willmitzer L \& Trethewey RN (2002). A review: Sucrose to starch: a transition in molecular plant physiology. Trends in Plant Sci 7(1): 35-41.

36. Marchal, L (1999). Towards a rational design of comercial maltodextrins a mechanistic approach. Deuchtland: Tramper and Bergsma Eds.

37. Blenkinsop RW, Copp LJ, Yada RY \& Marangoni AG (2002). Changes in compositional parameters of potato (Solanum tuberosum L.) during lowtemperature storage and their relationship to chip processing quality. J Agric Food Chem 50: 4545-4553.

38. Kumar D, Singh BP \& Kumar P (2004). An overview of the factors effecting sugar content of potatoes. Ann Appl Biol 145: 247-256.

39. DeWilde T, DeMeulenaer B, Mestdagh F, Verhé R., Govaert Y, Fraselle S, Degroodt JM, Vandeburie S, Demeulemeester K, Calus A, Ooghe W \& Peteghem CV (2004). Acrylamide formation during frying of potatoes: Thorough investigation on the influence of crop and process variables. Czech J Food Sci 22: 15-18.

40. Biedermann-Brem S, Noti A, Grob K, Imhof D, Bazzocco D \& Pfefferle A (2003). How much reducing sugar may potatoes contain to avoid excessive acrylamide formation during roasting and baking? Eur Food Res Technol 217: 369-373. 
41. Fauconnier ML, Beltran JR, Delcarte J, Dejaegh F, Marlier M \& Jardin P (2002). Lipoxygenase pathway and membrane permeability and composition during storage of potato tubers (Solanum tuberosum L. cv Bintje and Desiree) in different conditions. Plant Biol 4: 77-85.

42. Davey MW, Montagu MV, Inze D, Sanmartin M, Kanellis A, Smirnoff N, Benzie IF, Strain JJ, Favell D \& Fletcher J (2000). Plant L-ascorbic acid: chemistry, function, metabolism, bioavailability and effects of processing. J Sci Food Agric 89: 82586.

43. Larisch B, Pischetsrieder M \& Severin T (1996). Reaction of dehydroascorbic acid with primary aliphatic amines including $\mathrm{N}$ (alpha)-acethyllysine. $J$ Agric Food Chem 44: 1630-1634.

44. Hagg M, Hakkinen U, Kumpulainen J, Ahvenainen R \& Hurme E (1998). Effects of preparation procedures, packaging and storage on nutrient retention in peeled potatoes. $J$ Sci Food Agric 77: 519-526.

45. Robbins RJ (2003). Phenolic acids in foods: an overview of analytical methodology. J Agric Food Chem 51: 2886-2887.

46. Anthon GE \& Barrett DM (2002). Kinetic Parameters for the Thermal Inactivation of Quality-Related Enzymes in Carrots and Potatoes. $J$ Agric Food Chem 50: 4119-4125.

47. Madiwale GP, Reddivari L, Holm DG \& Vanamala J (2011). Storage elevates phenolic content and antioxidant activity but suppresses anti proliferative and pro-apoptotic properties of colored-flesh potatoes against human colon cancer cell lines. J Agric Food Chem 59(15): 81558166.

48. Gonzalez A, Cruza CSR, Valenzuelaa RC, Flelixa AR \& Wang CY (2004). Physiological and quality changes of fresh-cut pineapple treated with antibrowning agents. Lebensm Wiss. Technol 37: 369-376.

49. Martin FL \& Ames JM (2001). Formation of Strecker aldehydes and pyrazines in a fried potato model system. J Agri and Food Chem 49: 3885-3892.

50. Pedreschi F, Aguilera JM \& Pyle L (2001). Textural characterization and kinetics of potato strips during frying. J Food Sci 66: 314-318.

51. Jaswal AS (1991). Texture of French fried potato: quantitative determinations of non-starch polysaccharides. Am Potato J 68: 171177.

52. Segnini P, Dejmek P \& Oste R (1999). A low cost video technique for colour measurement of potato chips. Swiss Society Food Sci Technol 32: 216-222.

53. Mackay S (1999). Techniques and types of fat used in deep-fat frying; A policy statement and background paper prepared by Heart Foundation of New Zealand.

54. Stadler RH, Blank I, Varga N, Robert F, Hau J, Guy PA, Robert MC \& Riediker S (2002). Acrylamide from Maillard reaction products. Nature 419: 449-450.

55. Rodriguez SL \& Wrolstad R (1997). Influence of potato composition on chip color quality. Am Potato J 74: 87106. 